\title{
Ovarian and pituitary function in dogs after hysterectomy
}

\author{
B. Hoffmann ${ }^{1}$, R. Höveler ${ }^{1}$, S. H. Hasan ${ }^{2}$ and K. Failing ${ }^{3}$ \\ ${ }^{1}$ Ambulatorische und Geburtshilfiche Veterinärklinik Justus-Liebig-Universität Gießen, 6300 \\ Gießen, Germany; ${ }^{2}$ Schering AG, Müllerstraße 170-178, 1000 Berlin, Germany; and ${ }^{3}$ Institut für \\ Veterinär-Physiologie, Arbeitsgruppe Biomathematik, Justus-Liebig-Universität Gießen, 6300 \\ Gießen, Germany
}

\begin{abstract}
Summary. In studies of five hysterectomized and five control dogs, hysterectomy shortened the anoestrous interval $(96.6 \pm 28.0$ versus $149.4 \pm 50 \cdot 9$ days, $P<0.05)$. No differences in hormone concentrations (progesterone, oestradiol, prolactin and growth hormone) were observed between the control and hysterectomized dogs except for a brief fall in progesterone concentrations over 8 days immediately after surgery, between days 35 and 40 after onset of pro-oestrous bleeding; only these animals developed symptoms of overt pseudopregnancy. It is concluded that, in dogs, luteal regression occurs independently of a uterine luteolysin, but that the uterus may play a role in control of duration of anoestrus. Pseudopregnancy seems to be initiated by a fall in progesterone concentrations rather than by other hormonal changes.
\end{abstract}

Keywords: dog; hysterectomy; ovary; growth hormone; prolactin

\section{Introduction}

Domestic dogs are monoestrous and predominantly aseasonal breeders, with several months of anoestrus between active reproductive phases (Stabenfeldt \& Shille, 1977; Siegel, 1982). In contrast to other domestic animal species, luteal function is almost identical in pregnant and nonpregnant females, except that pregnant animals attain baseline concentrations of progesterone earlier owing to the immediate prepartum decline of this hormone (Concannon et al., 1978). The development of lactatio falsa (overt pseudopregnancy) in many nonpregnant bitches during the latter half of dioestrus might be related to this extended luteal lifespan (Shille \& Stabenfeldt, 1980; Concannon, 1987; Gerres et al., 1988). Endocrine control of gonadal, in particular luteal, function in dogs is poorly understood. The decline of plasma progesterone concentrations after hypophysectomy during the early or midluteal phase (Okkens et al., 1986) demonstrates the necessity of pituitary support. Both luteinizing hormone ( $\mathrm{LH})$ and prolactin must be considered luteotrophic. During the later luteal phase or late pregnancy, inhibition of prolactin by treatment with the dopamine agonist CB-154 significantly reduced progesterone concentrations (by $>90 \%$ ) or induced interruption of pregnancy (Conley \& Evans, 1984; Concannon et al., 1987). Injection of anti-LH-antiserum significantly reduced progesterone concentrations of plasma (by $76-93 \%$ ) in pregnant bitches (Concannon et al., 1987), but similar treatments during the early luteal phase induced only a temporary and less distinct decline of progesterone concentrations (Conley \& Evans, 1984; Concannon et al., 1987), showing that the luteotrophic activity of $\mathrm{LH}$ and prolactin is related to the reproductive stage. The observation that prostaglandin $\mathrm{F}_{2 \alpha}$ of endometrial origin induces luteal regression in most domestic animals (Anderson et al., 1969) led to studies in dogs. Both Hadley (1975) and Baker et al. (1980) observed a shortened luteal lifespan after hysterectomy and a luteotrophic factor of uterine origin was postulated by Hadley (1975). Chaffaux \& Thibier (1978) observed a decline in progesterone concentrations after hysterectomy in normal pregnant dogs, but not in dogs with pyometra or other pathological uterine contents and concluded that there was a 
luteotrophic factor of fetoplacental origin. Olson et al. (1984), however, observed no changes in luteal function after hysterectomy of pregnant and nonpregnant dogs, whereas Okkens et al. (1985) reported a reduction of progesterone concentrations without a shortened luteal lifespan. Jöchle et al. (1973) could not interrupt pregnancy after treatments with prostaglandin $F_{2 a}$, but observed only a temporary decrease in progesterone concentrations. Repeated treatments, however, induced abortions in some dogs at late stages of pregnancy; in the nonaborting animals, progesterone concentrations were reduced only temporarily (Concannon \& Hansel, 1977). These data are conflicting and allow only limited conclusions on whether and to what extent prostaglandin $F_{2 \alpha}$ of uterine origin acts as a luteolytic agent in dogs. In the present experiments, we attempted to define maintenance and resumption of gonadal function in intact and hysterectomized dogs by observing the animals over a long period and by monitoring progesterone and oestradiol concentrations. After determining prolactin in selected samples, it was hoped to gain related information on the availability of this gonadotrophic factor. Since pseudopregnancy is an inherent part of canine reproduction, possibly also resulting from interactions between luteal function and growth hormone (El Etreby, 1979), growth hormone was also determined in a series of samples.

\section{Materials and Methods}

\section{Animals and experimental design}

The experiments were performed over 2 years. Healthy bitches with proven fertility (3-6 years old; bodyweight $27-35 \mathrm{~kg}$ ) were removed successively from a pack of English Foxhounds and housed in groups of up to four in a kennel, with about $100 \mathrm{~m}^{2}$ outdoor space. A standard diet was provided with water ad libitum. Sexual behaviour, external genitalia and mammary gland development were examined once or twice a day. In addition to the developmental stage tested by inspection and palpation, the secretory activity of the mammary glands was recorded (colour and type of secreted fluid, spontaneous release or in response to applied pressure). Vaginal cytology and introduction of a male dog served for confirmatory purposes. Five control dogs were monitored through two complete reproductive periods (cycles I and II) with the exception of one animal, which had to be removed from the experiment during cycle II. In four other animals, hysterectomy was performed in cycle I between days 35 and 40 (day $37 \cdot 7 \pm 2 \cdot 2$ ) after onset of pro-oestrous bleeding and, in another dog, added later to the experiment, at the end of the luteal phase (progesterone concentration $16.3 \mathrm{nmol}^{-1}$ ); in all five dogs, a complete cycle (cycle II) was observed after hysterectomy.

Onset of pro-oestrous bleeding was considered as day 0 . Blood samples were taken at intervals of 2 days during pro-oestrus, oestrus, metoestrus, dioestrus and during a period of about 10 days before pro-oestrus (terminology according to Stabenfeldt \& Shille, 1977); otherwise, sampling was at intervals of 4 days during anoestrus, which was defined as the period when progesterone concentrations were $<3 \cdot 2 \mathrm{nmol}^{-1}\left(=1 \mathrm{ng} \mathrm{ml}{ }^{-1}\right)$. Progesterone and oestradiol were determined in all samples collected; prolactin and growth hormone were assayed in six cycles of the control group and in three cycles during and after hysterectomy.

\section{Hormone assay}

All hormones were determined by radioimmunoassay.

Progesterone. The method followed the procedure outlined by Hoffmann et al. (1973). Plasma (0.1 ml) was extracted with hexane, the antiserum used was directed against 4-pregnene-1 $\alpha-$-ol-3,20-dione-HS-bovine serum albumin (BSA) (final dilution 1:75000, $K_{\mathrm{a}}=3.42 \times 10^{9} \mathrm{~mol}^{-1}$ ). Intra- and interassay coefficients of variation were 14 and $15 \%$, respectively, the detection limit was at $0.19 \mathrm{nmol}^{-1}$.

Oestradiol. Initially, for the determination of oestradiol, high-performance liquid chromatography (HPLC) was applied before radioimmunoassay. After solid-phase extraction of $0.5 \mathrm{ml}$ plasma (Extrelut columns (Merck, Darmstadt, Germany), elution with $6.0 \mathrm{ml}$ tertiary-butyl-methyl-ether) and evaporation to dryness, the samples were redissolved in $0.6 \mathrm{ml}$ of $35 \%$ acetonitrile in water and an aliquot of $0.5 \mathrm{ml}$ was injected into the HPLC system (reversed-phase HPLC; column: Lichrosorb-RP 18 (Merck, Darmstadt), isocratic (40\% acetonitrile in water) and isothermal $\left(40^{\circ} \mathrm{C}\right)$ conditions, flow $\left.0.4 \mathrm{ml} \mathrm{min}{ }^{-1}\right)$. As established by runs with $\left[{ }^{3} \mathrm{H}\right]$-standards, the fraction containing the oestradiol (retention $24 \mathrm{~min}$ ) was collected in radioimmunoassay glass tubes and evaporated to dryness, and $0 \cdot 1 \mathrm{ml}$ BSA-phosphate buffer was added.

The radioimmunoassay was set up as a sequential assay (Strecker et al., 1979). After the addition of $0.4 \mathrm{ml}$ antiserum dilution (antiserum Gi- $\mathrm{E}_{2 \beta}-\mathrm{KI}$, obtained after immunization of rabbits with oestradiol-17 $\beta-6 \mathrm{CMO}-\mathrm{BSA}$; final dilution 1:20000; $K_{\mathrm{a}}=11.79 \times 10^{9} \mathrm{~mol} \mathrm{l}^{-1}$, crossreactions: oestrone, $1.30 \%$; oestriol, $0.68 \%$; all other tested nonphenolic steroids $<0.01 \%)$ to the samples and standards $(0.74 \mathrm{fmol}$ to $0.11 \mathrm{pmol}$ per tube in $0.1 \mathrm{ml}$ BSA-phosphate 


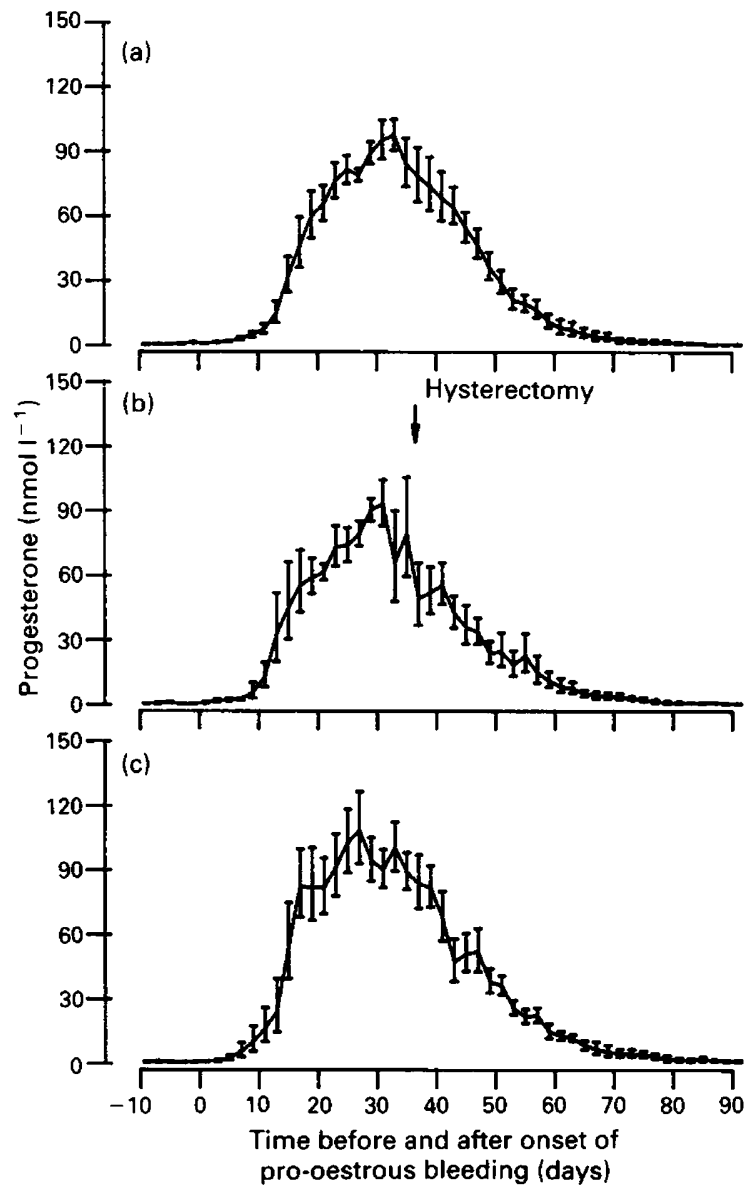

Fig. 1. Mean values of progesterone concentration $\left(\bar{x}_{\mathrm{G}} \cdot \mathrm{DF}^{ \pm 1}\right)$ in peripheral plasma of (a) control dogs (number of cycles, $n=9)$ and during (b) cycle I $(n=4)$ and (c) cycle II $(n=5)$ of hysterectomized bitches.

buffer), a first 'overnight' incubation (minimum $12 \mathrm{~h}$ ) at $4^{\circ} \mathrm{C}$ was performed. $\left[{ }^{3} \mathrm{H}\right]$ oestradiol $(0 \cdot 132 \mathrm{pmol}=0.444 \mathrm{KBq}$ per tube) was then added and the samples were again incubated for $45 \mathrm{~min}$ at $4^{\circ} \mathrm{C}$ (second incubation). After separation of free and bound steroid by addition of $0.2 \mathrm{ml}$ of ice-cold charcoal suspension $(0.5 \%$ charcoal, $0.05 \%$ dextrane) and centrifugation for $15 \mathrm{~min}$ at $2400 \mathrm{~g}$ and $4^{\circ} \mathrm{C}, 0.6 \mathrm{ml}$ of the supernatant was removed to measure the radioactivity of the bound fraction. Absolute binding of $\left[{ }^{3} \mathrm{H}\right]$ oestradiol was $15-20 \%$. As determined from plasma samples, mean recovery of $14.7(n=8), 29.4(n=8), 58.9(n=6)$ and $117.8(n=7)$ pmol oestradiol $1^{-1}$ was at $77 \%$, the mean intraand interassay coefficients of variations were 13 and $22 \%$, respectively. The lower limit of sensitivity was at $12 \cdot 6 \mathrm{pmol}$ $1^{-1}$. During the course of the experiments, sample purification by HPLC was omitted, since virtually identical results were obtained with and without chromatography. Instead, before radioimmunoassay, $0.25 \mathrm{ml}$ plasma was extracted twice with $3.0 \mathrm{ml}$ toluene.

Prolactin. Prolactin was measured by the method of Gräf et al. (1977): $300 \mu \mathrm{l}$ of plasma in duplicate and $100 \mu \mathrm{l}$ of standard were incubated with $200 \mu \mathrm{l}$ tracer $(9000$ c.p.m.) for $24 \mathrm{~h}$ at room temperature. The antibody-bound labelled prolactin was precipitated by adding $200 \mu \mathrm{l}$ of anti-rabbit gamma globulin in sheep (Schering, Berlin) in a dilution of 1:60, which provided maximum separation and, after further incubation for $24 \mathrm{~h}$, the resulting complex was then centrifuged at $3000 \mathrm{~g}$ for $20 \mathrm{~min}$ at $4^{\circ} \mathrm{C}$. The supernatant was discarded and the amount of precipitate was calculated. The minimum detectable concentration in the assay of these samples was $0.25 \mathrm{ng}$ per tube. The interassay coefficient of variation was $22 \%$.

Growth hormone. Growth hormone was measured essentially by the method of Cocola et al (1976): $400 \mu \mathrm{l}$ of plasma in duplicate and $100 \mu \mathrm{l}$ of standard were incubated with $200 \mu \mathrm{l}$ of antibody of appropriate dilution and $200 \mu \mathrm{l}$ tracer (14000 c.p.m.) for $48 \mathrm{~h}$ at room temperature. The antibody-bound labelled growth hormone was precipitated by adding $200 \mu \mathrm{l}$ of anti-monkey gamma globulin in goat (Paesel, Frankfurt) at a dilution of 1:10 which provided 
Table 1. Duration of luteal phase* and area under the curve (nmol day ${ }^{-1} 1^{-1}$ ) for peripheral progesterone for cycles I and II of control and hysterectomized dogs

\begin{tabular}{|c|c|c|c|c|c|c|}
\hline \multirow[b]{2}{*}{ Group } & \multirow[b]{2}{*}{$\begin{array}{c}\text { No. of } \\
\text { dog }\end{array}$} & & \multicolumn{2}{|c|}{ Cycle I } & \multicolumn{2}{|c|}{ Cycle II } \\
\hline & & & $\begin{array}{l}\text { Luteal phase } \\
\text { (days) }\end{array}$ & $\begin{array}{l}\text { Area under } \\
\text { curve }\end{array}$ & $\begin{array}{l}\text { Luteal phase } \\
\text { (days) }\end{array}$ & $\begin{array}{l}\text { Area under } \\
\text { curve }\end{array}$ \\
\hline \multirow[t]{7}{*}{ Control } & $101 \dagger$ & & 58 & $3165 \cdot 4$ & - & - \\
\hline & 102 & & 56 & $2956 \cdot 4$ & 59 & 2614.9 \\
\hline & 103 & & 60 & $2630 \cdot 2$ & 60 & $3104 \cdot 6$ \\
\hline & 104 & & 73 & $3418 \cdot 2$ & 75 & $5596 \cdot 2$ \\
\hline & 105 & & 102 & $3474 \cdot 2$ & 70 & 3323.7 \\
\hline & & $\overline{\mathrm{x}}_{\mathrm{G}}$ & $68 \cdot 0$ & 3112.9 & $65 \cdot 7$ & $3505 \cdot 5$ \\
\hline & & $\mathrm{DF}$ & 1.28 & $1 \cdot 11$ & $1 \cdot 12$ & 1.39 \\
\hline \multirow[t]{7}{*}{ Hysterectomized } & 301 & & 68 & $2826 \cdot 1$ & 86 & 3887.9 \\
\hline & $302 \ddagger$ & & - & - & 80 & 4282.5 \\
\hline & 303 & & 64 & $2031 \cdot 7$ & 70 & $2306 \cdot 8$ \\
\hline & 304 & & 68 & $3474 \cdot 8$ & 58 & $4686 \cdot 0$ \\
\hline & 305 & & 62 & $3132 \cdot 3$ & 64 & $4092 \cdot 0$ \\
\hline & & $\overline{\mathbf{x}}_{\mathrm{G}}$ & 65.5 & $2800 \cdot 6$ & 70.9 & $3744 \cdot 8$ \\
\hline & & $\mathrm{DF}$ & $1 \cdot 05$ & $1 \cdot 27$ & $1 \cdot 17$ & $1 \cdot 32$ \\
\hline
\end{tabular}

${ }^{*}$ Period with progesterone $>3 \cdot 2 \mathrm{nmol}^{-1}\left(=1 \cdot 0 \mathrm{ng} \mathrm{ml}^{-1}\right)$.

†Had to be removed during cycle II.

†Surgery during late luteal phase.

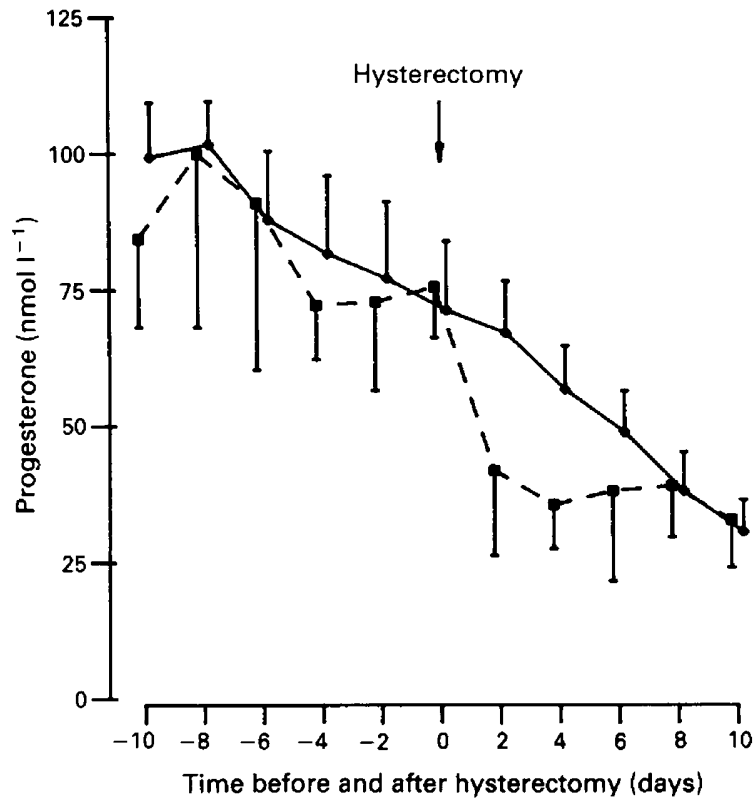

Fig. 2. Mean values of progesterone concentration $\left(\bar{x}_{\mathrm{G}} \cdot \mathrm{DF}^{ \pm 1}\right) 10$ days before and after hysterectomy during midcycle (days 35-40) $(-\square-n=4)$ and in control dogs $(-\bullet-n=9)$ during the respective periods. 


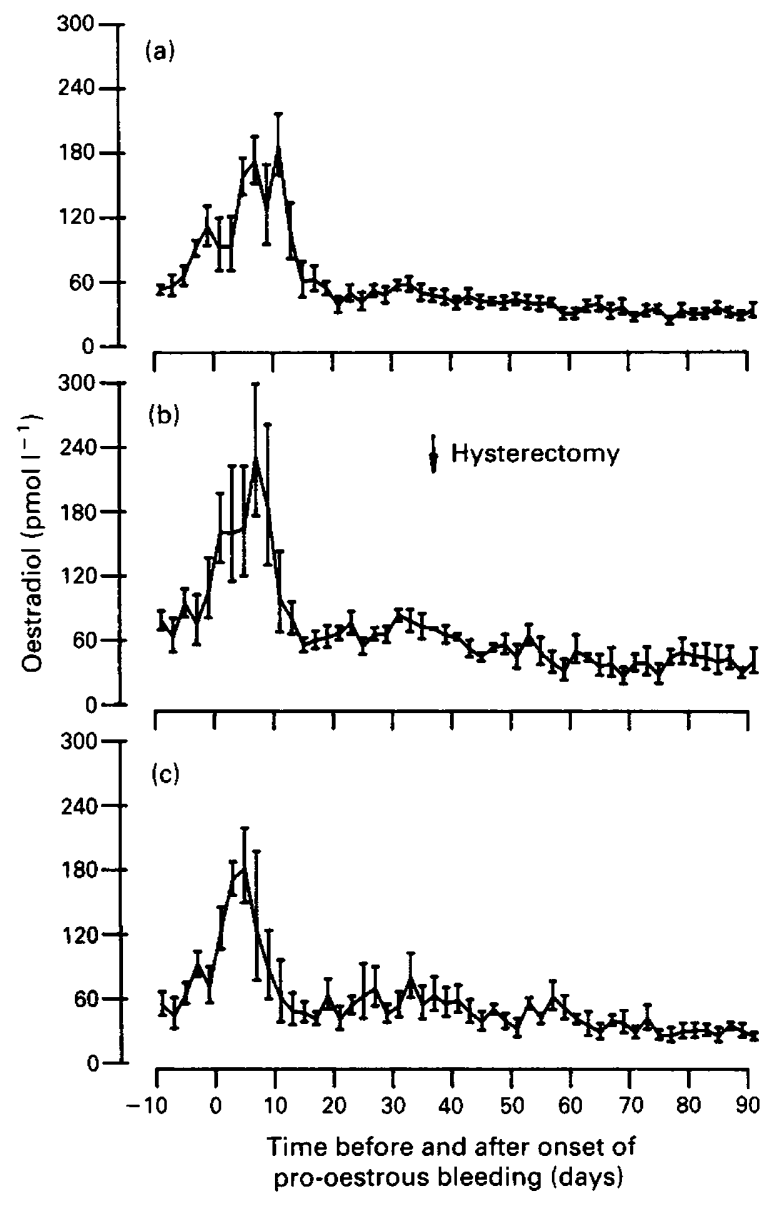

Fig. 3. Mean values of oestradiol concentration $\left(\bar{x}_{\mathrm{G}} \cdot \mathrm{DF}^{ \pm 1}\right)$ in peripheral plasma of (a) control dogs (number of cycles, $n=9)$ and during (b) cycle I $(n=4)$ and (c) cycle II $(n=5)$ of hysterectomized bitches.

\section{Statistical evaluation}

To cope with the asymmetrical distribution of hormone plasma values, which are often positively skewed, the geometric means $\left(\bar{x}_{G}\right)$ and dispersion factors (DF) were calculated (Sachs, 1984). Results were expressed as $\bar{x}_{G}$. DF \pm 1 . Arithmetic means were calculated for the anoestrous intervals. A two-factorial analysis of variance with repeated measures on the factor time was used to test for time and group differences with respect to the experimental design. To describe availability of hormones over time as an indicator of hormone production, the area under the curve was calculated (in nmol day ${ }^{-1} 1^{-1}$ ) (Dost, 1968). All statistical evaluations were done with the BMDP statistical software (Dixon, 1987).

\section{Results}

No significant differences in the course of progesterone concentrations were evident between cycles (Fig. 1). Table 1 gives the individual data and the mean values for the duration of the luteal phase (progesterone $>3.2 \mathrm{nmol}^{-1}$ ) and the respective area under the curve. However, there was a drop in progesterone concentrations over 8 days in the four animals hysterectomized between days 35 and 40 (Fig. 2); these dogs, but not the control animals, developed symptoms of overt 


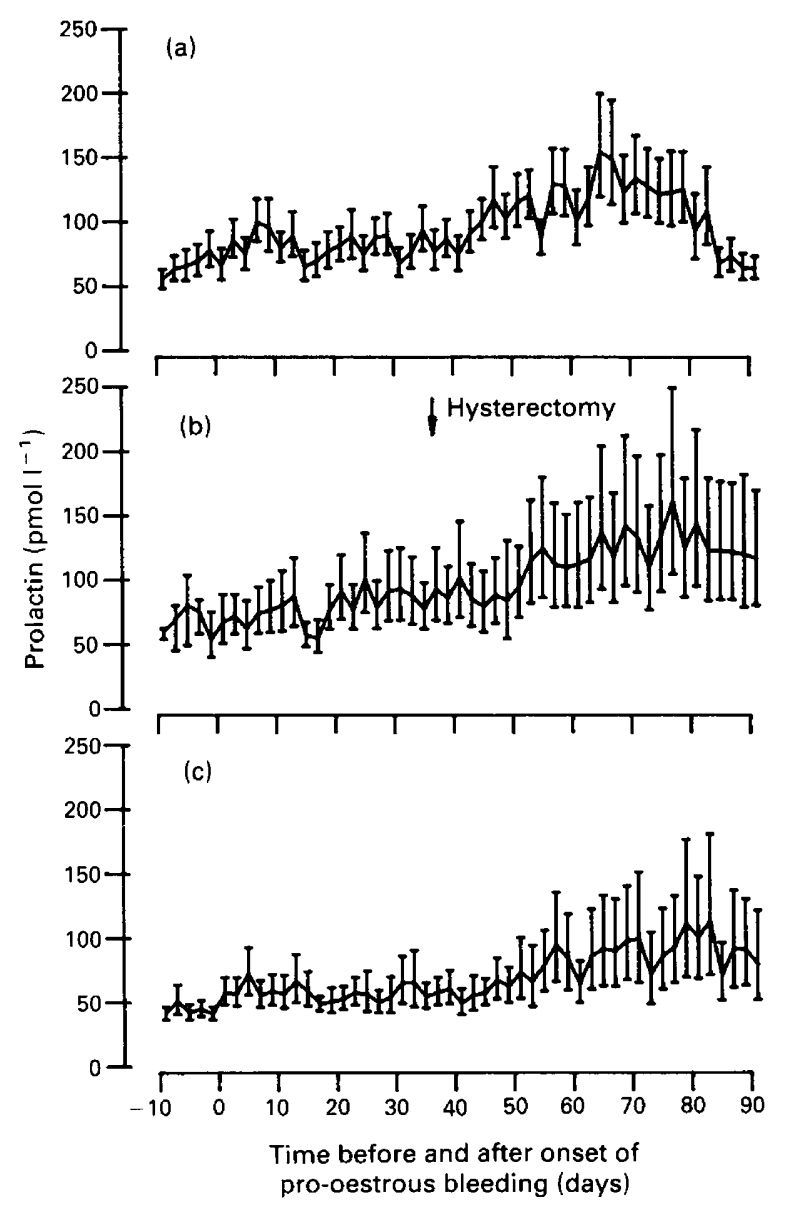

Fig. 4. Mean values of prolactin concentration $\left(\bar{x}_{\mathbf{G}} \cdot \mathrm{DF}^{ \pm 1}\right)$ in peripheral plasma of (a) control dogs (number of cycles, $n=6)$ and during (b) cycle I $(n=3)$ and (c) cycle Il $(n=3)$ of hysterectomized bitches.

pseudopregnancy, as was indicated by enlargement of mammary glands and secretion on pressure of the caudal mammary complexes.

No differences in concentrations of oestradiol, prolactin and growth hormone were found between control and hysterectomized animals or between cycles I and II in the hysterectomized dogs (Figs 3, 4 and 5).

Whereas progesterone, oestradiol and prolactin concentrations significantly changed over time $(P<0.0001)$, no such effects could be established for growth hormone. The average anoestrous interval between cycle I and cycle II was significantly $(P<0.05)$ longer in the control $(149.4 \pm 50.9$ days) than in the hysterectomized dogs $(96 \cdot 6 \pm 28 \cdot 0$ days) (Table 2$)$. This was tested by means of the two-sample $t$ test, not assuming equal variances.

\section{Discussion}

There were no differences between the control group and the hysterectomized animals for any of the hormones determined (progesterone, oestradiol, prolactin and growth hormone). There was also no difference between the cycle when hysterectomy was performed and the next cycle. In 


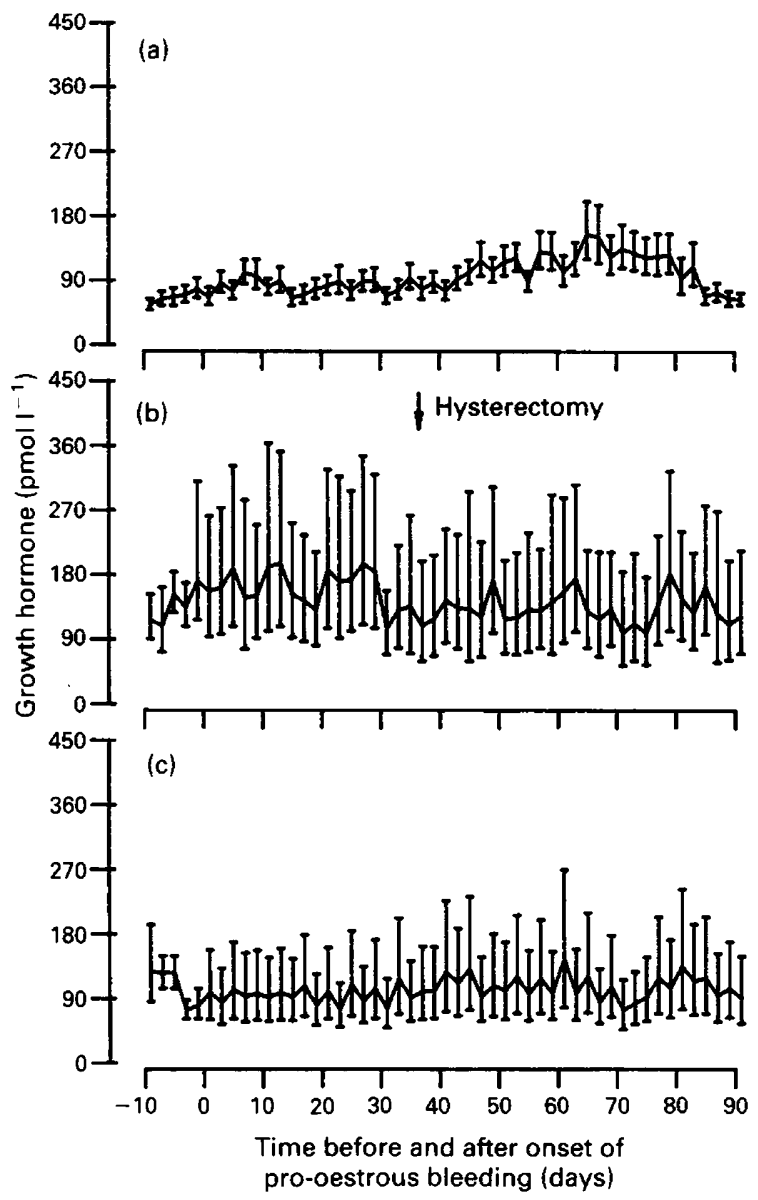

Fig. 5. Mean values of growth hormone concentration $\left(\bar{x}_{\mathrm{G}} \cdot \mathrm{DF}^{ \pm 1}\right)$ in peripheral plasma of control dogs (number of cycles, $n=6)$ and during (b) cycle I $(n=3)$ and (c) cycle II $(n=3)$ of hysterectomized bitches.

Table 2. Onset and duration of anoestrus* in control and hysterectomized dogs

\begin{tabular}{|c|c|c|c|c|c|}
\hline \multirow[b]{2}{*}{ Group } & \multicolumn{4}{|c|}{ Anoestrus } & \multirow[b]{2}{*}{ Difference } \\
\hline & $\begin{array}{c}\text { No. of } \\
\text { dog }\end{array}$ & Onset & $\begin{array}{l}\text { Length } \\
\text { (days) }\end{array}$ & $\bar{x} \pm \mathrm{SD}$ & \\
\hline \multirow[t]{5}{*}{ Control } & 102 & 17 July & 238 & & \\
\hline & 103 & 5 February & 129 & & \\
\hline & 104 & 19 August & 116 & $149 \cdot 4 \pm 50 \cdot 9$ & \\
\hline & 105 & 7 June & 118 & & \\
\hline & 106 & 14 June & 146 & & \\
\hline \multirow[t]{5}{*}{ Hysterectomized } & $30 \mathrm{I}$ & 27 July & 79 & & \\
\hline & 302 & 28 April & 115 & & \\
\hline & 303 & 9 August & 112 & $96 \cdot 6 \pm 28 \cdot 0$ & $P<0.05 \dagger$ \\
\hline & 304 & 19 May & 121 & & \\
\hline & 305 & 21 February & 56 & & \\
\hline
\end{tabular}

*Length between cycles with progesterone $<3.2 \mathrm{nmol} \mathrm{l}^{-1}\left(=1.0 \mathrm{ng} \mathrm{ml}^{-1}\right)$.

†Compared with the control group. 
agreement with previous observations (Olson et al., 1984; Okkens et al., 1985), these observations provide further evidence that in nonpregnant dogs luteal regression does not depend on a uterine luteolysin and that normal reproductive cycles follow hysterectomy. However, the uterus may have an influence on the length of the period of anoestrus, which was significantly shortened after hysterectomy (97 versus 149 days). Clearly, in view of the small number of dogs investigated, this observation needs further confirmation. Thus, high variability has been reported for the length of anoestrus in dogs (Christie \& Bell, 1971; Concannon, 1987) and the season of the year may play a role, though in both groups of animals anoestrus commenced between February and August. Hysterectomy led to an immediate decrease of progesterone by about $50 \%$ compared with the control animals; after 8 days, progesterone concentrations in the control group and hysterectomized animals were the same. This temporary decrease of progesterone, which did not affect the general area under the curve established for the whole cycle, was associated with the appearance of symptoms of overt pseudopregnancy. Similar observations have been made by Okkens et al. (1985) and would support the conclusions of Gerres et al. (1988) (they could provoke onset of pseudopregnancy in dogs after treatment with the antigestagen RU 38486) that removal of progesterone is one of the triggers for overt pseudopregnancy. Since there were no differences between the cycles of the control animals and the second cycle of the hysterectomized animals, this temporary reduction in progesterone cannot be interpreted as a removal of a uterine luteotrophic factor (Hadley, 1975), but, rather, as a consequence of surgery, possibly by interfering with ovarian blood supply.

In contrast to progesterone, oestradiol and prolactin, no changes in relation to stage of the cycle could be established for growth hormone. Although only a few animals were investigated, this observation seems to indicate that growth hormone has little importance, if any, in the development of pseudopregnancy. Thus the increases in growth hormone concentrations and activity of growth hormone cells in the pituitary gland after treatment of dogs with progestagens (Gräf \& El Etreby, 1979) must be interpreted carefully in respect of the mechanism underlying mammary gland development and onset of pseudopregnancy. In addition, the prolactin concentrations were not different between cycles; although the sampling intervals of 2 days allow only conclusions with respect to baseline concentrations, the lack of any shift does not point towards the role of this hormone in the development and initiation of pseudopregnancy.

The present data yield further evidence that in dogs luteal regression occurs independently of a uterine luteolysin. However, the uterus may play an active role in controlling the length of anoestrus. No evidence has been obtained that prolactin and growth hormone are associated with the initiation of overt pseudopregnancy, which seems to be a result of the decrease in progesterone concentrations during the second half of dioestrus.

With support of the German Research Foundation (DFG).

\section{References}

Anderson, L.L., Bland, K.P. \& Melampy, R.M. (1969) Comparative aspects of uterine-luteal relationships. Recent Progress in Hormone Research 25, 57-65.

Baker, B.A., Archbald, L.F., Clooney, L.L., Lotz, K. \& Godke, R.A. (1980) Luteal function in the hysterectomized bitch following treatment with prostaglandin $\mathrm{F}_{2 a}\left(\mathrm{PGF}_{2 a}\right)$. Theriogenology 14, 195-205.

Chaffaux, S. \& Thibier, M. (1978) Effets de l'hysterectomie sur la concentration de progesterone plasmatique chez la chienne. Recueil de Medicine Vétérinaires 154, 933-938.

Christie, D.W. \& Bell, E.T. (1971) Some observations on the seasonal incidence and frequency of oestrus in breeding bitches in Britain. Journal of Small Animal Practice 12, 159-167.

Cocola, F., Udeschini, G., Secchi, C., Panerai, A.E., Neri, P. \& Müller, E.E (1976) A rapid radioimmunoassay method of growth hormone in dog plasma. Proceedings of the Society for Experimental Biology and Medicine 151, 140-145.

Concannon, P. (1987) The physiology of ovarian cycles, pregnancy and parturition in the domestic dog. In Proceedings of the Annual Meeting of the Society for Theriogenology and The American College of Theriogenologists, pp. 159-197. Society for Theriogenology, Hastings, NE, USA. 
Concannon, P. \& Hansel, W. (1977) Prostaglandin $\mathrm{F}_{2 a}$-induced luteolysis, hypothermia, and abortions in Beagle bitches. Prostaglandins 13, 533-542.

Concannon, P., Butler, W.R., Hansel, W., Knight, P.J. \& Hamilton, J.M. (1978) Parturition and lactation in the bitch: serum progesterone, cortisol and prolactin. Biology of Reproduction 19, 1113-1118.

Concannon, P., Weinstein, P., Whaley, S. \& Frank, D. (1987) Suppression of luteal function in dogs by luteinizing hormone antiserum and by bromocryptine. Journal of Reproduction and Fertility 81, 175-180.

Conley, A. \& Evans, L. (1984) Bromergocryptine induced abortion in the bitch. Proceedings of the $10 \mathrm{th}$ International Congress on Animal Reproduction and Artificial Insemination, University College, Dublin, Ireland, Vol. 1, p. 504.

Dixon, W.J. (1987) BMDP Statistical Software Manual. University of California Press, Berkeley, pp. 359-387.

Dost, F.H. (1968) Grundlagen der Pharmakologie. Georg Thieme, Stuttgart, pp. 267-271.

El Etreby, M.F. (1979) Effect of cyproterone acetate, levonorgestrel and progesterone on adrenal glands and reproductive organs in the Beagle bitch. Cell and Tissue Research 200, 229-243.

Gerres, S., Höveler, R., Evers, P. \& Hoffmann, B. (1988) Investigations on the role of progesterone (P4) in the endocrine control of overt pseudopregnancy in the bitch, application of an antigestagen. Proceedings of the llth International Congress on Animal Reproduction and Artificial Insemination, University of Illinois at Urbana, Champaign, USA, Vol. 2, p. 90.

Gräf, K.J. \& El Etreby, M.F. (1979) Endocrinology of reproduction in the female dog and its significance in mammary gland tumorigenesis Acta Endocrinologica 90, Supplement 222, pp. 1-34.

Gräf, K.J., Friedrich, E., Matthes, S. \& Hasan, S.H. (1977) Homologous radioimmunoassay for canine prolactin and its application in various physiological states. Journal of Endocrinology 75, 93-103.

Hadley, J.C. (1975) The effects of serial uterine biopsies and hysterectomy on peripheral blood levels of total unconjugated oestrogen and progesterone in the bitch. Journal of Reproduction and Fertility 44, 389-393.

Hofimann, B., Kyrein, H.J. \& Ender, M.L. (1973) An efficient procedure for the determination of progesterone by radioimmunoassay applied to bovine peripheral plasma. Hormone Research 4, 302-310.

Jöchle, W., Tomlinson, R.V. \& Andersen, A.C. (1973) Prostaglandin effects on plasma progesterone levels in the pregnant and cycling dog (Beagle). Prostaglandins 3, 209-217.

Okkens, A.C., Dieleman, S.J., Bevers, M.M. \& Willemse, A.H. (1985) Evidence for the non-involvement of the uterus in the lifespan of the corpus luteum in the cyclic dog. Veterinary Quarterly 7, 169-173.

Okkens, A.C., Dieleman, S.J., Bevers, M.M., Lubberink, A.A.M.E. \& Willemse, A.H. (1986) Influence of hypophysectomy on the lifespan of the corpus luteum in the cyclic dog. Journal of Reproduction and Fertility 77, 187-192.

Olson, P.N., Bowen, R.A., Behrendt, M.D., Olson, J.D. \& Nett, T.M. (1984) Concentrations of progesterone and luteinizing hormone in the serum of diestrus bitches before and after hysterectomy. American Journal of Veterinary Research 45, 149-153.

Sachs, L. (1984) Angewandte Statistik. Springer Verlag, Berlin, pp. 70-89.

Shille, V.M. \& Stabenfeldt, G.H. (1980) Current concepts in reproduction of the dog and cat. Advances in Veterinary Science and Comparative Medicine 24, 211-230.

Siegel, E.T. (1982) Endokrine Krankheiten des Hundes. Paul Parey Verlag, Berlin, pp. 179-187.

Stabenfeldt, G.H. \& Shille, V.M. (1977) Reproduction in the dog and cat. In Reproduction in Domestic Animals, 3rd edn, pp. 499-527. Eds H. H. Cole \& P. T. Cupps. Academic Press, New York.

Strecker, H., Hachmann, H. \& Seidel, L. (1979) Der Radioimmunotest (RIA), eine hochspezifische extrem empfindliche quantitative Analysenmethode. Chemiker Zeitung 103, 53-68.

Received 12 December 1991 